\title{
From Dai Viet to the August Revolution
}

\section{“INDOMITABLE” VIETNAMESE IN HISTORY}

For more than a thousand years, starting in I I I BCE, the Vietnamese were vassals of China, part of its frontier province of Jiaozhi (Giao Chi to the Vietnamese). At that time, they resided mostly in and around the Red River Delta. The rest of what is now Vietnam, including its Central and Southern regions, belonged to other ethnic groups. The Vietnamese staged several rebellions during the millennium of Chinese rule; all failed. Only in 939 CE, following the spectacular triumph by Ngo Quyen (898944) over a Chinese fleet on the Bach Dang River near Ha Long Bay the year before, did they finally regain their independence. Over the next seven decades, rival clans vied to rule the now-sovereign nation. This First Vietnamese Civil War ended in Ioo9, with the founding of the Ly Dynasty, which branded its kingdom "Dai Viet" in ro54 and made Thang Long, now Hanoi, its capital. For the first time, Vietnamese lived under a government of their own in an ostensibly independent country.

Independence remained precarious, however. The Chinese continued to harbor designs over Dai Viet, and invaded again in I075. They were ousted four years later by forces under the command of General Ly Thuong Kiet (I0I9-II05), who famously used a poem entitled "Mountains and Rivers of the Southern Country" (Nam quoc son ha) to motivate his troops before battle. The poem reads:

The Southern country's mountains and rivers the Southern Emperor inhabits.

The separation is natural and allotted in Heaven's Book.

If the bandits come to trespass it,

You shall, in doing that, see yourselves to be handed with failure and shame! 
Regarded by the Vietnamese as their first Declaration of Independence, the poem has since served as a hymn to their courage and desire to live freely, as well as a rallying cry against China and other external threats to Vietnamese sovereignty and territorial integrity.

Then the Mongols came. On three occasions during the thirteenth century (I258, I285, and I287-8) the hordes of Kublai Khan, grandson of Genghis, attacked Dai Viet from China, which they had previously conquered. Each time the Vietnamese were equal to the task. Conscious of their relative military inferiority, they fought the invaders with guerrilla tactics, conducting lightning raids and attacking supply lines instead of engaging in large battles. Their final victory in a naval engagement, on the aforementioned Bach Dang River in I288, was credited to the military genius of one of their commanders, Tran Hung Dao (I228-I300). No sooner had they reclaimed their own country from the Mongols than the Chinese attacked again and successfully subjugated Dai Viet in I407. Le Loi (I384-I433) and his armies drove them out twenty-one years later.

Ngo Quyen, Ly Thuong Kiet, Tran Hung Dao, Le Loi, and others who led campaigns against the Chinese and Mongols dominate the pantheon of Vietnamese folk heroes. They personify what is arguably the most defining aspect of the Vietnamese national character according to the Vietnamese themselves: their strength, courage, and indomitability in the face of foreign aggression. This ethos, defined in terms of an unshakable will to be masters of their own collective destiny, is a tremendous source of pride among Vietnamese. It is also, in their own eyes, a testament to their keen sense of ethnic identity and solidarity from early times, to their long and glorious tradition of embracing, variously, nationalism (love of nation) and patriotism (love of country).

But as historian William Turley points out, "the image of heroic resistance to foreign rule" and the "myth of indomitability in the face of superior force" are just that: myth. ${ }^{\mathrm{I}}$ The uprisings that took place during the millennium of Chinese domination - and produced their fair share of national heroes - were typically localized, confined to small areas; they were not nationwide resistance efforts fueled by nationalist or patriotic sentiment. Also, there was nothing distinctively anti-Chinese about them. Rebellions happened just as frequently under sovereign Vietnamese rule, and for the same reason: peasants detested pronounced government intrusion upon their lives. ${ }^{2}$ Lastly, the underlying claim that Vietnamese developed through these resistance efforts and other endeavors an acute sense of nationalism and patriotism early in their history is simply untrue. Average Vietnamese at the time were unable to even fathom the meaning 
of "nation," as their world rarely extended beyond their native villages. Loyalty was to their own families and local communities, not to the nation or state, however defined in premodern and early modern times. When Vietnamese banded together to fight foreign aggressors, it was because the central government conscripted them to do so, or their families and communities were directly threatened; it was not a voluntary, instinctive gesture to serve the greater national good, as historians in Vietnam and elsewhere have long maintained. Not until the twentieth century, after colonization by France, a totally alien country, did Vietnamese acquire a sense of what it meant to be a distinct nation, and the willingness to sacrifice in its name. But even then, national political organizations and their leaders had to mold popular thinking and behavior.

\section{EARLY EXPANSION \& CIVIL WAR}

As Dai Viet monarchs endeavored to create a functional state and keep foreign aggressors at bay, they launched a series of vicious campaigns against their own neighbors to the South and West. These campaigns were products of both necessity - to squash external threats and acquire land and resources for a growing population - and sheer imperial ambition. The Vietnamese "march to the South," as historians call the nation's southward expansion, came largely at the expense of the Chams, a seafaring people closely related to the Malays of Malaysia and Indonesia who used to occupy present-day Central and parts of Southern Vietnam. It culminated in the seizure of large swaths of territory, including the Mekong River Delta, Vietnam's most fecund “rice basket," from the Cambodian kingdom of Angkor (802-I43I). As this demonstrates, the Vietnamese were as capable of victimizing others as they were victimized themselves; they dished out as much as they absorbed. "Aggression against the southern neighbors of Champa and Cambodia rivaled the struggle against foreign invasion" for the Vietnamese, historian Mark Moyar has rightfully noted. ${ }^{3}$

Owing to its late incorporation into the realm controlled by the Vietnamese, the southern half of their country remained until recently an eclectic borderland far less homogenous ethnically and culturally than its northern part. That and other differences between the Northern and Southern populations, plus the polarizing role of provincialism, muddled the Vietnamese identity, which became acutely manifest when the Second Civil War broke out in I6I3. That war resulted from a conflict between rival clans, the Trinh and Nguyen, based in Northern and Southern Dai 
Viet, respectively. Each clan claimed to defend the honor of the hapless Le Dynasty, but in fact sought to fulfill its own self-serving political and financial agenda. The ensuing savage internecine struggle lasted nearly two centuries and congealed the separate, distinct identities of Northern and Southern Vietnamese. That civil war, the "worst infighting in Vietnamese history" according to one source, ended after armies of disaffected peasants led by three brothers vanquished the Nguyen (I 777), and then the Trinh (I786), before overthrowing the Le Dynasty (I788) in the Tay Son Rebellion.

Seeking to capitalize upon the prevailing turmoil and restore their dominion over Dai Viet, the Chinese invaded again. Their armies retreated promptly, however, following a surprise Vietnamese attack on the eve of the lunar New Year - Tet in Vietnamese - in I789. The architect of this first "Tet Offensive" was Nguyen Hue (I753-92), one of the Tay Son brothers, who had declared himself Dai Viet's new ruler the year before. As Emperor Quang Trung (reigned I788-92), he became the first Vietnamese sovereign to exercise effective control over all that is now Vietnam. National unity still remained precarious, however, as domestic disputes and conflict kept plaguing the country, leaving it deeply fractured. Historian Edward Miller has sensibly argued that Vietnamese politics and identities were, in retrospect, conditioned "less by any external rivalry with China" and other foreign aggressors than by "the fierce internal competition" among Vietnamese themselves. ${ }^{4}$

Unsurprisingly, the peace imposed by Quang Trung and his so-called Tay Son Dynasty ( $\mathrm{I} 788-\mathrm{I} 802$ ) did not last. Intent on restoring the power and wealth of his family, a surviving member of the just-vanquished Nguyen clan, Nguyen Phuc Anh (I762-I 820), began plotting against the Tay Son. Anh enlisted the help of a French priest, Pigneau de Behaine (I74I-99), and other Western missionaries to procure men, arms, and munitions (Jesuits, the largest missionary order, had been debarking in the region since the early seventeenth century). In I787, Anh sent his own son, escorted by de Behaine, to France to plead for aid directly from King Louis XVI (reigned I774-92). The King responded favorably, but because of miscommunication Anh received only a fraction of the aid pledged to him. Still, that aid was enough to meet his needs. Flanked by a motley crew of soldiers and mercenaries from France and elsewhere who also trained his own soldiers in modern warfare and helped him build a naval fleet, Anh overthrew the Tay Son and founded the Nguyen Dynasty (I802-I945). As Emperor Gia Long (reigned I802-4I), he made Hue, in the center, his capital. Following consultations with the Chinese court, 
which he sought to appease and win over, he adopted "Viet Nam" as the name of his country in I 804 . Despite its unification under a single, imperial government, the country remained internally divided and fragile.

\section{ENTER FRANCE}

In soliciting assistance from France to claim the mantle of imperial power, Gia Long sowed the seeds of his own nation's demise. For the help they rendered, the French demanded special rights and privileges as concerned trade and Catholic missionary activity in Vietnam. Beholden to them, the Emperor had little choice but to meet their demands. His son and successor, Minh Mang (reigned I 820-4I), was of a different mind, however. He felt he owed the French nothing, and committed himself instead to building a modern, centralized, bureaucratically-controlled, Confucian-oriented, and fiercely independent state. As part of his travails, he renamed the country "Dai Nam" and created three administrative zones: Bac Ky in the north, Trung $\mathrm{Ky}$ in the center, and Nam Ky in the south. As he expanded his realm, largely at the expense of Cambodia and Laos, he also sought to homogenize it. Concerned about the creeping, socially divisive influence of France in his domain, he prohibited the practice of Catholicism, including missionary work, and went as far as destroying churches and forcing Vietnamese converts to recant. His successors Thieu Tri (reigned I 84 I-7) and Tu Duc (reigned I 847-83) went even further, executing foreign missionaries and indigenous priests and imposing tight restrictions on foreign trade that effectively closed off their country to the outside world.

The apparent ingratitude of Gia Long's successors and, specifically, their persecution of Catholics, who numbered five percent of the Vietnamese population by then, incensed decision-makers back in Paris. In I 858 , following the execution of two Western missionaries by Tu Duc, a punitive expedition under Francis Garnier (I839-I 873) arrived in Dai Nam. Its deployment was equally motivated by the aspiration of the French monarch, Napoleon III, to enhance French global prestige and satisfy the desires of banking and business leaders in France who wanted to exploit Dai Nam's human and material potential while establishing a springboard for accessing Chinese markets and resources. This was, after all, the age of High Imperialism, when European and other industrializing countries "scrambled" for colonies in Asia, Africa, and the Pacific.

The Nguyen Dynasty and its armies did their best to resist the invaders, to no avail. Their efforts were too poorly coordinated, and enemy firepower too overwhelming. The French slowly but gradually 
consolidated their control over Southern Dai Nam before moving against the North and, finally, going after the seat of Nguyen power in Hue. After the French stormed his palace in 1885 , the ruling emperor, a boy named Ham Nghi (reigned I 884-5), fled the capital and became nominal leader of a resistance movement, Can Vuong ("Help the King"), aiming to drive out the French and return Ham Nghi to power. This was a royalist, not a nationalist, movement. Lacking popular appeal and competent leadership and organization, it fizzled out after a few years. Following Ham Nghi's flight from Hue, the French appointed his brother, the compliant Dong Khanh (reigned I 885-9), emperor. Tempted as they were to abolish the Nguyen Dynasty, the French opted instead to preserve and rule through it, giving a veneer of legitimacy to their actions in Vietnam. Nguyen monarchs counted among France's most willing accomplices thereafter.

By the turn of the century, France had become master of not just Vietnam but of the neighboring kingdoms of Laos and Cambodia as well, portions of which the Vietnamese had previously incorporated into Dai Nam. This collection of territories eventually became known as French Indochina. Vietnam offered the most promise for economic gain and the pursuit of France's "civilizing mission," but also posed the greatest challenge. Its population was substantially larger than that of either Laos or Cambodia, and more prone to rebel. Seeking to nip in the bud future pretensions of nationalist resistance, the French split Dai Nam into three separate entities, more or less along the same regional administrative lines previously decreed by Minh Mang: Bac Ky in the north became "Tonkin," Trung Ky in the center became "Annam," and Nam Ky in the south became "Cochinchina." The French also banned use of the names "Dai Nam" and "Viet Nam." The "Indochinese Union" thus consisted of five "countries" (pays) built upon the foundation created by the Nguyen Dynasty and Minh Mang in particular. Owing to the political fracture of Vietnam by France, the different regimes imposed on each region, and the management style of the French, the Vietnamese lived vastly different experiences under European colonialism. Those experiences amplified existing social and ethnic cleavages that tore at the fragile fabric of Vietnamese society even as failed resistance efforts nurtured the myth of national indomitability.

\section{COLONIAL ERA}

Exploitation, suffering, and misery characterized French rule in Vietnam. In Cochinchina, a colony under France's direct control (unlike the other 
four Indochinese territories, known as "protectorates," ruled indirectly through local agents including the Nguyen Dynasty), the French organized and managed the production for export of rice, mostly to Hong Kong and China. In Tonkin and Annam, it was tea and coffee destined for European markets. To optimize yields, colonial authorities concentrated land in the hands of a few wealthy landlords and entrepreneurs able to afford the latest industrial farming tools. The practice dispossessed poor peasants and small farmers, who became marginalized sharecroppers, tenant farmers, and wage laborers. It also widened the income gap between rich and poor. By the I930s, the majority of peasants in Tonkin and Annam were landless, and among those who owned land, holdings were so small that some ninety percent could barely feed themselves and their families. In Cochinchina, where French imperialism was most aggressive, seventy-five percent of peasants were landless. Never before had Vietnamese lives been so extensively and widely disrupted, and the authority of the presiding government more ubiquitous.

Starting in the I920s, the French set up large rubber plantations to meet rising demand in the United States, where Henry Ford had recently begun mass-producing automobiles thanks to his perfection of the assembly line. The Michelin brothers, owners of a caoutchouc factory in France, became significant stakeholders in the Indochinese rubber industry. Conditions for workers on plantations, and on the Michelin-owned one at Phu Rieng north of Saigon in particular, were appalling. The labor was unforgiving, claiming the lives of one in every four workers by some accounts. In Tonkin, the extraction of coal destined for Chinese and Japanese markets, another lucrative enterprise for the French, required miners to spend most of their days underground, breathing filthy air. Miners endured even more privation and hardship than plantation workers. Mining sites in fact became known as "death valleys." At the height of the colonial era, more than I00,000 Indochinese labored on plantations, 52,000 in mines, and 86,500 in industrial and commercial enterprises. The French also exported thousands of Vietnamese laborers to their colonies in Polynesia, New Hebrides, New Caledonia, and on Reunion Island.

Wage laborers and poor peasants alike escaped the drudgery and misery of everyday life by consuming copious amounts of opium and rice alcohol. Well aware of that, French authorities monopolized the production and sale of both commodities, in addition to salt, ensuring steady revenue streams and the docility of consumers. Approximately twenty percent of the wealth France generated in Indochina came from the three monopolies. To move goods and labor within Vietnam and between 
Vietnam and China, the French built miles of railway tracks. In I9Io, they completed a rail line connecting the port city of Haiphong to Kunming in Southern China. In 1936, they opened the Hanoi-Saigon line. The development and modernization of the country's transport infrastructure and the upgrade of irrigation systems were among the positive legacies of the colonial era in Vietnam, as was the creation of an industrial sector to satisfy local demands for concrete, textiles, cigarettes, and beer (the famous 33, because it came in cans of thirty-three centiliters, renamed 333 after I975) and other beverages. But none of these projects grew out of altruistic concerns; they either profited Europeans financially, facilitated their colonial domination, or both.

For a handful of Vietnamese, French colonial rule was a boon. Families that collaborated with the colonizers and became complicit in the exploitation and dispossession of their own compatriots reaped significant dividends. Those included access to French schools in Vietnam and universities in France for their children, positions in the colonial administration, even rights to full French citizenship. Vietnamese enthralled by French culture renounced "backward" local traditions and adopted Western lifestyles. They converted to Catholicism, gave themselves and their children French names, wore the latest Parisian fashions, drank wine, vacationed on the French Riviera, and befriended and even married Europeans. The most notable collaborators were the members of the Nguyen Dynasty, as previously noted. After Dong Khanh's investiture, it reached an agreement with colonial authorities permitting it to retain its titles and wealth in exchange for tacit endorsement of the French colonial project. Nguyen rule thus continued uninterruptedly, although emperors were reduced to figureheads with little authority.

Across Vietnam, as in the rest of Indochina during the high tide of colonialism, executive power rested with the Governor General in Hanoi, an omnipotent consul of sorts who answered to the Ministry of Colonies back in Paris. A colonial bureaucracy managed day-to-day affairs. Most lower-level bureaucrats were indigenous collaborators: ethnic Vietnamese for the most part, since the French considered the Khmer (Cambodians) and Lao to be lesser, more indolent "breeds." Over time, the colonial regime employed 27,000 Vietnamese as administrators, postal workers, customs agents, and secretaries, and an additional I6,000 as teachers. A good number of those collaborators and members of their families, Catholics in particular, doggedly supported the anti-communist regime in Saigon and its American patrons during the Vietnam War. France also relied on ethnic Chinese and brought in Indians, mostly Christians from 
its enclave at Pondicherry, to help manage Indochina. The fewer white faces local subjects encountered, the French reasoned, the less likely they would be to revolt against European domination. This reasoning reflected the "conquer-and-divide" approach Western powers typically employed to meet their goals in overseas dependencies. It also enabled France to keep the cost of running Indochina reasonable. Indeed, at no point during the colonial era were there more than 34,000 metropolitan French citizens working and living there. Considering that the Indochinese population surpassed 22 million in I940, that attested to both the ingenuity of colonial authorities in developing effective control mechanisms, and the important role played by local collaborators and Chinese and Indian contract workers. Other expatriate communities in Indochina included Americans, businessmen and missionaries for the most part, and Japanese.

Whatever the extent of their support for France, and regardless of the degree of their assimilation into French culture, non-whites were never treated as equals by Europeans. As in all colonies they owned, whites dominated the social hierarchy and enjoyed exclusive rights and privileges. Race was always the ultimate determinant of social status. Thus, poor, uneducated French nationals (petits blancs, or "small whites") ranked above wealthy, erudite Vietnamese. Over time, discriminatory practices and attitudes frustrated even collaborators. For no matter how much Vietnamese individuals "bought" into the colonial system and became "civilized" by European standards, whites always judged them by the color of their skin and not their merits and contributions.

Discrimination, intimidation, coercion, and violence were the primary instruments of colonial domination. Starting in I9I7 a colonial police force, the Sûreté générale, monitored the activities of actual and potential dissidents, relying on a vast network of informants. A colonial army consisting of a small French Gendarmerie, a larger Native Guard (Garde indigène) of indigenous soldiers known as tirailleurs under French officers, and, after I930, an infantry regiment of the French Foreign Legion formed the main safeguards against rebellion. Those Indochinese found guilty of threatening the stability and security of the colony and otherwise acting in ways detrimental to the French colonial project were either executed - usually by the guillotine - or sentenced to lengthy prison terms and hard labor. Political dissidents, if spared execution, often ended up in "tiger cages" on Con Dao Island, off the southern tip of the Ca Mau Peninsula in the South, or at the infamous Maison Centrale in downtown Hanoi (Hoa Lo penitentiary to the Vietnamese, which became the 
"Hanoi Hilton," a prison for American prisoners-of-war [POWs], during the Vietnam War).

Prisoners regularly endured beatings, torture, food and sleep deprivation, and other forms of abuse. Many did not survive incarceration. Those who did came out more radicalized than reformed, fanatically committed to ending French colonial control and restoring Vietnam's independence. In the I930s, Vietnamese communist leaders actually tasked Party members behind bars to recruit and indoctrinate fellow inmates. Colonial prisons held in excess of I0,000 political prisoners in the period I9306 . They became virtual "revolutionary universities," breeding and training grounds, for the Vietnamese communist and nationalist movement. Portraits of communist luminaries, including Karl Marx (I8I 8-83) and Vladimir Lenin (I870-I924), actually hung on the walls of some prison halls. French authorities themselves acknowledged that convicts who did not come out of their prisons dead came out "red," the color of communism. Hard time done in prison became a badge of honor, courage, and merit for communists, and even served as criteria for promotion through Party ranks. The common experience of incarceration also bonded Party members to each other. Top communist leaders during the Vietnam War had all endured and been hardened by long stints in colonial jails, which largely explained their unanimity of purpose, steely resolve, refusal to compromise, and determination to win at any cost.

\section{WORLD WAR I \& RUSSIAN REVOLUTION}

The outbreak of World War I (I9I4-8) in Europe had major implications for the Vietnamese. France, like other belligerents, drew extensive human and material resources from its colonies to support its war effort. It enlisted some 90,000 Vietnamese as combatants and support personnel, logistical supply hands and factory workers for the most part. Some combatants came from tirailleurs regiments; others volunteered for military service in Europe, lured by signing bonuses, salaries, and promises of pensions for their families. Hoping to receive French citizenship and other benefits after hostilities ended, Vietnamese gave a good account of themselves wherever and in whatever capacity they served.

After the war ended, most Vietnamese servicemen had to return home and resume their lives as second-class citizens in their own country. Only a handful remained in France, becoming the nucleus of the Vietnamese community there, along with students who never returned. Anger at French authorities, compounded by the carnage they had witnessed 
during the war, prompted many returning veterans to openly question France's supposed civilizational superiority and denounce its rule in Vietnam. Admittedly, nothing had been "civilized" about the way European governments had fought the war, sending young men to their deaths by the hundreds of thousands in human wave attacks showing callous disregard for human life. In exposing the myth of white racial superiority, the "war to end all wars" encouraged Vietnamese, and veterans of World War I among them in particular, to actively challenge French dominion over their nation. That challenge inspired a new generation of anti-colonial, patriotic activists.

Equally stirring for young Vietnamese patriots was the Russian Revolution of I9I7. In the midst of World War I, Vladimir Lenin and the Bolsheviks claimed the mantle of power in Russia and, after a bloody civil war (1917-22), founded the Soviet Union. The Bolshevik Party, renamed the Communist Party of the Soviet Union (CPSU) after the Revolution, was a "vanguard" organization of committed revolutionaries inspired by the writings of Karl Marx to reinvent Russian society on behalf of workers, the "proletariat," oppressed by greedy industrialists, the "bourgeoisie." Its penultimate goal was to create a dictatorship of the people leading to the establishment of communism, a radical socio-economic and political order characterized by common ownership of land and commercial enterprises, the absence of social classes, the elimination of government controls and then of the government itself, and, at last, universal equality and harmony. Just months before the I9I7 Revolution, Lenin had penned Imperialism: The Highest Stage of Capitalism. Based on Marxist theories, the essay unabashedly denounced colonialism as the supreme stage of capitalist development to secure maximal profits for the avaricious bourgeoisie. The triumph of "Marxism-Leninism" - the fusion of Marx's ideas about social revolution with Lenin's methods to bring it about - in Russia and the advent of the Soviet Union resonated across the colonial world, including Vietnam. After all, rarely had Westerners themselves so overtly condemned colonialism, by now a pillar of their own societies' economic and foreign policy and virtual hallmark of their civilization, much less brazenly called for its abolishment.

\section{RISE OF VIETNAMESE PATRIOTISM}

The rigors of life under colonial rule produced widespread disenchantment, frustration, and anger among Vietnamese long before World War 
I exposed the limits of French civilizational greatness and the Russian Revolution roused young patriots. This shared experience to no insignificant degree contributed to the emergence of patriotism as a popular, mass phenomenon in Vietnam, as did increased literacy rates resulting from the colonial school curriculum and the adoption of quoc ngu, a system of writing based on the Latin script and easier to learn than the traditional system based on Chinese characters, as the Vietnamese vernacular language (although some ninety percent of the people remained illiterate under French rule). From the inception of the colonial system in the late nineteenth century, various individuals and groups had attempted to abolish and otherwise restrain it. All had failed, proving no match for the Sûreté and colonial armed forces. Even simple calls for reform fell on deaf ears, as French authorities believed that compromise signaled weakness and would only embolden indigenous activists. Intransigence was the best deterrent against subversion, the authorities thought. Poor organization and coordination compounded by uncharismatic leadership largely accounted for the inability of Vietnamese patriots to rally more supporters and rattle colonial authorities early on.

The first individual to distinguish himself as a bona fide patriotic leader because he was able to tap the budding patriotic fervor of his compatriots was Phan Chu Trinh (I872-1926). Trinh served in the imperial bureaucracy until he could no longer stomach the Nguyen Dynasty's collaboration with France. The year of Japan's victory in the Russo-Japanese War (1904-5), he quit the mandarinate and traveled to Tokyo, as many young Eastern Asian nationalists were doing at the time as part of the "Go East" movement. There, he studied Japan's remarkable transformation from victim of Western imperial aggression to victor in a war against a European power. Following his return to Vietnam, Trinh called for abolishing the Vietnamese monarchy and replacing it with a republican system, albeit under French tutelage because he did not think his compatriots were ready for total independence. He was not a revolutionary in the literal sense, but a reformist seeking incremental changes to French rule. Trinh abjured violence as a political tool. He believed Vietnamese patriots should educate themselves instead of fighting, learn about France's democratic and liberal traditions so they could replicate them in their own country later on. He admired France, its republican values in particular, and even appealed directly to Paris for help in preparing the Vietnamese for independence. Under the careful watch of the Sûreté he opened the Tonkin Free School in I907 to teach young Vietnamese modern values, including nationalism and patriotism. Colonial authorities 
shut it down within a year, and sentenced Trinh to three years on Con Dao Island before deporting him to France, where he met and worked with a man named Nguyen Ai Quoc. Trinh returned to Vietnam in I925, and died the following year.

Though unsuccessful in realizing his aspirations, Trinh had a marked impact on the Vietnamese political landscape of the early twentieth century, inspiring as he did a generation of younger Vietnamese to advocate for change. Equally important in that respect was his contemporary and acquaintance, but not relation, Phan Boi Chau (I867-I940). Chau was the "Vietnamese icon of the anti-colonial struggle," according to political scientist Céline Marangé. 5 His father had been active in earlier resistance efforts against France, which inspired the young Chau to dabble in anti-colonialism. In 1904, the latter founded the Vietnam Modernization Association, an anti-colonial organization modeled after the Can Vuong movement, with the dissident Nguyen Prince Cuong De (I882-I95I) as nominal head. Struggling financially, the association turned to Japan for assistance. Chau moved to Tokyo in I905, meeting Phan Chu Trinh there shortly thereafter. He then went to China, where he fell under the spell of Sun Yat-sen (I 866-I925), the architect of Republican China, and developed close ties to other Chinese nationalist leaders. Upon his return to Vietnam around the time of the I9I I Revolution in China, he became a republican and founded the Vietnamese Restoration League (VRL), a political party modeled after Sun's Chinese United League that became the Chinese Nationalist Party (Guomindang, GMD) after the I9I I Revolution. The VRL's chief goals were ending French colonial control, reunifying Vietnam, abolishing the monarchy, and establishing a democratic republican system.

Unlike Trinh, Chau sought the complete and immediate overthrow of the colonial order, not its reform, by force if necessary. After returning to China, where he met Soviet representatives for the first time, and being briefly detained by French agents there, Chau traveled to the Soviet Union to study its political ideology and solicit assistance from its leaders to liberate Indochina. Moscow, its political system, the I9I7 Bolshevik Revolution, and the Russian people generally impressed Chau, who subsequently urged his compatriots to establish contacts with Soviet decision-makers and the organ they had recently established to export communism, the Comintern (Communist International, I9I9-43). Chau returned to China in 1925, and was arrested again by French agents. Possibly, he was betrayed by the aforementioned Nguyen Ai Quoc, a fellow nationalist presumably jealous of his stature and disapproving of 
his political agenda. Following his transfer to Vietnam, Chau was placed under house arrest. His political activities remained limited until his death in 1940 .

Together, the two Phans made seminal contributions to the awakening and growth of the Vietnamese national and patriotic consciousness. They stand out for their ability to arouse the anticolonial passions of their compatriots, for attuning them to the bond they shared as victims of French colonialism, and also, interestingly, for their admiration of American revolutionary ideals (i.e., freedom from foreign tyranny and quest for justice) and republican values (i.e., liberty and unalienable individual rights). They are considered the founding fathers of contemporary Vietnamese patriotism, and role models for the next generation of more radical activists. The two Phans also set up connections with Chinese nationalists, on the one hand, and Soviet communists, on the other, both of whom made invaluable contributions to the struggle for independence and self-government in Vietnam. Chau's ideas were particularly important in inspiring formation of the Vietnamese Nationalist Party (known by its Vietnamese acronym, VNQDD), a mildly socialist revolutionary party calling for the colonizers' violent overthrow, which became the first dissident political organization to develop a mass following in Vietnam. The VNQDD gained notoriety in 1929 for assassinating Alfred François Bazin, the much-reviled Director of the Office of Indochinese Labor tasked with recruiting workers for plantations in Cochinchina and the French territories of New Caledonia and New Hebrides, whom many Vietnamese held personally responsible for the abuses they or their relatives suffered. The VNQDD's growth and popularity were stunted, however, by its inability to appeal to and coopt peasants.

Circumstances galvanized the Vietnamese masses and made them receptive to radicalized patriotic callings in the I920s, and to MarxismLeninism specifically. Heavy taxation, mounting personal debt, the inability to own land or ownership of only small parcels of it, and growing economic inequality exasperated peasants. Some had to cede as much as seventy percent of their crop as levy to landlords and/or colonial authorities. Workers on plantations, in mines, and in the budding industrial sector endured interminable workdays, backbreaking labor, and low wages. Beatings and other forms of corporal punishment were common for those failing to meet employers' expectations. As most workers had signed long-term contracts and vast distances separated them from their native villages - those employed on rubber plantations in Cochinchina, to illustrate, were typically recruited in Tonkin - quitting or simply 
walking away was not an option. Besides, punishment for "runaways" was harsh, and included public execution by hanging, stabbing, or some other cruel method to deter others from doing the same. Contract laborers were not slaves in the traditional sense, but their workplace conditions certainly made them feel like they were. The Great Depression that began in late 1929 aggravated the condition of peasants and workers as France attempted to mitigate the impact of the financial crisis at home by extracting more wealth from its colonies. By the turn of the new decade, Vietnam was ripe for revolution.

\section{HO CHI MINH}

Only one Vietnamese individual stands above Phan Chu Trinh and Phan Boi Chau for his ability to inspire and rally his compatriots in support of national independence. That person is Nguyen Ai Quoc, known later in life as Ho Chi Minh (1890-1969). Ho was born Nguyen Sinh Cung in an impoverished part of Nghe An Province, in Northern Annam. His father was a Confucian scholar, teacher, and low-level administrator (District Chief) in the imperial bureaucracy. Ho studied under him before attending the prestigious National College, a high school for the sons of the elite, in Hue. Other illustrious graduates from this school include Vo Nguyen Giap (I9II-20I3) and Pham Van Dong (I906-2000), who later became Ho's closest allies in the communist movement, and Ngo Dinh Diem (190I-63), the future President of South Vietnam and Ho's arch-nemesis in the I950s and early 6os. In Hue Ho studied French history and language, and became struck by the dissonance between the liberal values France championed at home and its exploitative practices abroad. Against the wishes and intentions of French authorities, the study of French and the colonial school system in general favored the development of a patriotic consciousness among Vietnamese. In fact, they "opened up a whole new world for Vietnamese youth who came of age in the r920s and afterwards," as Ho's own experience demonstrates. ${ }^{6}$

Frustrated by his lack of prospects after graduation, and embarrassed by his father's recent demotion for fatally beating a man while intoxicated, Ho got a job as a kitchen helper on a French steamer and left the country in I9II, at age twenty-one. He would not return to Vietnam for thirty years. He first went to Marseille, in France, and applied to the French Colonial Administrative School there. He was rejected. Finding employment on ships, he traveled the world. He visited several African countries and spent time in the United States, in Harlem and Brooklyn, 
before settling temporarily in the United Kingdom. During his travels, Ho developed a keen interest in the human condition and the suffering endured by men because of the greed of other men, including American blacks at the hands of whites. He also developed a knack for relating to people from different socio-economic and racial backgrounds, facilitated over time by his knowledge of French, Chinese, Russian, Thai, and English. The educated and the rich respected his worldliness; the poor and the oppressed were struck by his capacity to empathize with them. The ability to bridge the gap between those with means and those without served his revolutionary purposes well later. "It was Ho Chi Minh's ability to move between these different realms which finally secured his place as the most successful leader of the independence struggle" in Vietnam, biographer Sophie Quinn-Judge surmises. ${ }^{7}$

In I9I7 Ho settled in Paris as Nguyen Tat Thanh and connected with Phan Chu Trinh. With Trinh's encouragement, he penned newspaper articles calling for the independence of Vietnam under the pseudonym Nguyen Ai Quoc (Nguyen the Patriot). He met and developed personal bonds with other Asian nationalists in France, including Zhou Enlai (I898-1976), a future leader of the communist movement in China. Ho founded the Association of Annamese Patriots in the summer of I9I9 to rally patriotic Vietnamese exiles in France. During the Versailles Peace Conference that year, Ho and his exiled compatriots petitioned the allied victors of World War I for Vietnamese independence on the basis of US President Woodrow Wilson's Fourteen Points of January I9I8. The petition cited the American Declaration of Independence for good measure. The allies completely ignored it.

\section{INDOCHINESE COMMUNIST PARTY}

Concluding that appealing to Western sensibilities to secure Vietnam's independence was a waste of time, Ho searched for alternatives. Extremism and militancy, he reasoned, might be necessary to meet his purposes. Marxism-Leninism, the radical political philosophy embraced by the Soviet Union and increasing numbers of nationalists from the colonial world, particularly intrigued him. By many accounts, Ho was drawn to Marxism-Leninism after reading Lenin's Theses on the National and Colonial Questions, which pugnaciously denounced imperialism, like his Imperialism essay.

Marxism-Leninism, it turned out, not only explained the suffering of Ho's compatriots under the French, but also provided a blueprint for 
ending that suffering, for bringing down the colonial apparatus and replacing it with a representative regime to ensure that no man or woman ever again suffered because of another. That blueprint included forming a vanguard, a party of professional, committed operatives to spearhead the struggle for national liberation; establishing one-party rule, a "dictatorship of the proletariat," after independence; centralizing economic planning and abolishing capitalist practices, including private ownership of land and commercial enterprises; redistributing wealth; and practicing internationalism by actively supporting revolutionary movements in other countries. The ultimate objective of Marxism-Leninism was to bring about communism, namely, classlessness and governance by the concept of "each according to his ability, to each according to his need." The appeal of that blueprint was enhanced by the fact that the Soviet Union had created a special outfit in I9I9, the aforementioned Comintern, to guide vanguard parties and assist them logistically, materially, and financially in meeting their goals. According to historian Odd Arne Westad, Marxism-Leninism was "valuable" in the eyes of nationalists from the colonial world because it was "structured, defined, and first and foremost scientific." 8

In I920, while still in France, Ho became a founding member of the French Communist Party (PCF, its French acronym) and a staunch advocate of revolution in the colonial world. He traveled to Moscow in 1923 to study Marxism-Leninism and communism at the renowned University of Toilers of the East. There, he met other aspiring revolutionaries, including Josip Tito (I 892-I980), the future leader of Yugoslavia. He also became a Comintern agent, specializing in propaganda and political mobilization. His first mission, in I924, was to make contact with expatriate Vietnamese intellectuals in Guangzhou (Canton), in Southern China, and "convert" them to Marxism-Leninism. Guangzhou was by then the main base of operation and planning for Vietnamese revolutionaries in exile, a veritable breeding ground for radical nationalists and patriots. Ho established the Vietnamese Revolutionary Youth League, or Thanh nien, shortly after his arrival there. The League, whose members included Vo Nguyen Giap and Pham Van Dong, supported anticolonial and class struggle to bring about national liberation. It morphed into the Communist Party of Indochina (CPI) in I929. With assistance from his old friend Zhou Enlai, Ho was able to offer his followers training in various Chinese communist and nationalist political and military schools. He also married his first wife, a native of Guangzhou, during his time there. 
In Hong Kong in February of the following year, the CPI merged with two other Vietnamese communist organizations to form the Vietnamese Communist Party (VCP). Consistent with Ho's wishes, the VCP made national independence, to be pursued jointly with other nationalist organizations, communist or not, its priority. Ho effectively aspired to create a united front that took no account of the socio-economic background of its members to achieve Vietnamese independence. Communism would come later. Ho's emphasis on national independence, his lack of enthusiasm for class struggle, and his relatively cautious attitude toward revolutionary violence did not sit well with radicals within the VCP. Trained and indoctrinated in Comintern schools in Moscow, the radicals espoused the Stalinist, ultra-leftist position endorsed by the Comintern in 1928 that fighting domestic class enemies, "class warfare," was as important as fighting foreign imperialists. In their reckoning, Ho was not doctrinaire enough; he was too pragmatic, too moderate. He was too much of a nationalist, and not enough of a communist. In their eyes, Ho lacked "ideological rigidity," as Sophie Quinn-Judge put it.9

During a second meeting of VCP leaders in Hong Kong in October I930, the radicals slammed Ho and the Party's "moderate" line. After deliberation, the leaders adopted a new strategy calling for a two-stage revolutionary process. In the first stage, the Party would harness patriotism and nationalism to mobilize members of all social classes to defeat colonial authorities, secure national independence, and reunify the three Vietnamese entities of Tonkin, Annam, and Cochinchina. Upon completion of this "bourgeois nationalist revolution," the Party would instigate the second stage, the "communist revolution," characterized by formation of a new government, a so-called dictatorship of the proletariat; class struggle, that is, chastisement and neutralization of "reactionary," "bourgeois," and other domestic class enemies; confiscation of land and property belonging to landlords and redistribution among poor peasants; collectivization of agriculture; nationalization of businesses and other commercial enterprises; introduction of an eight-hour workday; abolition of unfair taxes and other harmful financial practices; democratic freedoms, including free education and health care; and equality between men and women. Communal bliss would ostensibly ensue.

At the behest of the Comintern, and to underscore the shift away from Ho's nationalist agenda, the leaders rechristened their organization the Indochinese Communist Party (ICP). Since Laotian and Cambodian communists were few, the Vietnamese themselves would assume responsibility for leading the revolution in those countries. Besides, ICP leaders 
thought, Vietnam would never enjoy the fruits of its independence unless French authority was abolished across the entire Indochinese Peninsula; Cambodia and Laos must form a "security belt" along Vietnam's western border. Tran Phu (I904-3I), a radical detractor of Ho Chi Minh newlyreturned from Moscow, was selected to become the new Party chief.

At once, the ICP set out to consolidate and grow itself, train operatives to become skillful propagandists, and achieve a higher degree of organizational unity and discipline. Tran Phu considered organization and rank-and-file members' respect for rules and procedures key to mobilizing and preparing the masses for meaningful political and economic action, including strikes and boycotts, and, in due course, armed insurrection. Only a mass movement, he and other communist leaders thought, could bring about the demise of the colonial system and its replacement with a new political and socio-economic order under an enlightened revolutionary government. The fixation of these leaders with organization, discipline, and mass mobilization, their no-nonsense approach and unwavering commitment to the liberation, reunification, and reinvention of Vietnam, became in time defining characteristics of the communist movement in that country. Those same characteristics also constituted the most important reason the Party ultimately met most of its goals, including defeating the United States in the Vietnam War, in the "Vietnamese Revolution," as they called their undertaking.

Though he would soon become the face of Vietnam's struggle for independence and his popularity at home and abroad only increased over time, Ho was never able to shed his reputation as a moderate, a "softie," among his more doctrinaire comrades within the Party. The latter would in fact do their best to limit Ho's influence within the Vietnamese communist movement, and even marginalize him. It took nearly three decades, but in the end they were able to accomplish just that. By then the war against the United States was about to get underway, and had it not been for the sideling of Ho by his own, radical peers at that critical juncture, that war's course and outcome could have been vastly different.

\section{ARMED ANTI-COLONIALISM}

In I930-I, against the backdrop of economic hardships resulting from the Great Depression and natural calamities, the ICP, VNQDD, and other political parties fomented popular unrest. In the Yen Bai mutiny of February 1930, Vietnamese tirailleurs radicalized and supported by the VNQDD murdered five and seriously wounded three of their white 
officers. Their own peers loyal to France neutralized them before they could cause more mayhem. About a month later, a popular uprising broke out in the Northern Annam provinces of Nghe An and Ha Tinh. This socalled Nghe-Tinh uprising consisted of I 25 separate incidents, namely, strikes, demonstrations, and revolts - some spontaneous, others incited by communist agents - directed against the French colonial administration and the Nguyen Dynasty and its mandarinate, seen as corrupt and responsible for the humiliation and suffering endured by the Vietnamese. The uprising brought peasants and workers together in sizeable numbers for the first time. Spurred by ICP and other radicals, the rebels murdered mandarins, landlords, and civil servants. They also set fire to government buildings, police stations, churches, and other symbols of foreign domination and oppression.

The response of colonial authorities to these treacherous acts was swift, and deadly. More than a thousand rebels and possibly twice that number of innocent civilians were killed in "pacification" and subsequent "mopping up" operations that included aerial bombings raids. Scores more died of malnutrition during incarceration in makeshift detention or "concentration" camps. Two hundred colonial troops died suppressing the Nghe-Tinh uprising, only one of whom was a French national. The superior firepower of colonial troops sealed the fate of insurgents, as did the latter's own lack of organization. In the aftermath of these troubles, colonial authorities aggressively hunted down members of dissident political organizations to prevent and deter future protests. Many were found and executed, and hundreds of their supporters were sent to prison, forced labor camps, or into exile. In 1930-2 colonial authorities sentenced nearly 7,000 Vietnamese for political crimes, executing eightyeight. Most ICP leaders and operatives involved in the events of I930-I were killed or captured, including Tran Phu, the Party head. Ho himself was briefly detained by the British police in Hong Kong.

Miraculously, the ICP survived, but its remnants had to seek refuge in Guangzhou, and reconstitute their organization there under the guise of the Overseas Bureau of the ICP. The VNQDD, the most popular and best organized party at the time, was not so lucky; French retaliation eviscerated it. That proved a boon for the ICP, which thereafter dominated the nationalist movement in Vietnam, and for its ideology, Marxism-Leninism, which became the driving force behind Vietnamese anti-colonialism and the default creed of patriots hoping to make a difference. The failed revolts of I930-I impressed upon ICP leaders the imperative need to closely coordinate the activities of its members, to 
develop superior organizational skills and discipline, to muster popular support, and to prepare its members for combat. They would also need to unite peasants, workers, and other suitable classes in common struggle against the colonial oppressor. To these ends, Ho went back to Moscow in 1934 to undergo further training at the International Leninist School for cadres.

The brutal crackdown on Vietnamese rebels generated public outcry in France. In conjunction with the Great Depression, which underscored the perils of capitalism, and other challenges, misrule in the colonies emboldened French progressives and other liberals. In 1936, a left-wing coalition including communists swept to power in Paris. At once, the new government of Prime Minister Leon Blum (in office 1936-7, 1938), the so-called Popular Front, loosened colonial controls, most notably over the indigenous press, and pardoned political prisoners. More than I, 500 prisoners were reprieved in Indochina alone. The impact of these measures on the Vietnamese anti-colonial movement was electric. The lifting of restrictions on free speech and the release of hardened and unrepentant members breathed new life into the ICP, and may well have saved the communist movement in Vietnam. In I936-7, communists and other leftists formed a united front and organized strikes, boycotts, and other such actions against the colonial establishment. Never to be outdone, the Sûreté clamped down harshly on the ICP, decimating its leadership ranks, again.

Although it lasted less than two years, the Popular Front's tenure in France markedly impacted the struggle for independence and reunification in Vietnam. The same was also true of the rapid industrialization and socialist transformation of the Soviet Union under Josef Stalin (I 8781953), the Spanish Civil War (1936-9), and the rise of Adolf Hitler (I889-1945) in Germany. Troubled and distracted by these alarming developments, policymakers in Paris paid less attention to the situation in Indochina. Admittedly, Japanese aggression in Asia concerned them, but not enough to beef up the French military and security presence in Indochina. Vietnamese communists took advantage of these distractions to reconstitute and grow their organization, train cadres, and spread their message among peasants and workers. By 1938 , the ICP comprised 202 members in Tonkin, 483 in Annam, and 655 in Cochinchina, and enjoyed patronage from nearly 30,000 workers and peasants countrywide. Still, its presence and influence nationwide remained negligible, especially in cities. 
WORLD WAR II

The onset of war in Europe in September 1939 marked a turning point for Indochina. France conscripted more than I.5 million Indochinese, mostly Vietnamese, to serve as soldiers and workers in its fight against Nazi Germany. Confronted by the rigors of war and desperate to improve its financial situation, it increased taxes as well as rents across Indochina, and introduced new tariffs on imports. It also reduced Indochinese workers' wages even as it extended their working hours to seventy-two per week. But that did nothing to save France. By the summer of I940, German troops were marching in the streets of Paris. By order of an agreement signed in September that same year between Germany's allies in Tokyo and the collaborationist Vichy government in France, which remained in charge of overseas territories, the Imperial Japanese Army earned the right to station some 6,000 troops and use three airfields in Indochina. Less than a year later, Vichy and Tokyo signed another, more comprehensive agreement allowing the Imperial Japanese Army to use Indochina as a base of operation in exchange for French autonomy in managing Indochinese affairs.

French colonial authorities served the Japanese in Indochina as the Vichy regime served the Germans in France. Abetted by the Japanese, they brutally cracked down on Vietnamese patriotic and other dissident political organizations. The state of war, the authorities claimed, mandated that they act without mercy. French security forces even went after their own white compatriots loyal to the Free France movement of General Charles de Gaulle (I890-I970), who condemned collaboration with fascism. Collusion with Japan saved the colonial apparatus in the short term, but irreversibly damaged French credibility among Indochinese. The latter were flabbergasted to see Europeans prostrate themselves before fellow Asians just to keep their privileged status. Japanese efforts to coopt the Indochinese with calls of "Asia for Asians," even as they worked alongside the French, fueled Vietnamese patriotic and anti-colonial passions.

Prompted by the Comintern, in late 1940 the ICP attempted to capitalize on the new situation and the apparent vulnerability of the French by instigating armed insurrections as well as mutinies among colonial troops where conditions permitted. The hasty, ill-conceived move proved disastrous. The French crushed the insurgents, killing or capturing most ICP leaders, yet again, including all so-called radicals who had previously studied in Moscow and dutifully observed Comintern revolutionary 
prescriptions. Yet again, however, the Party would find a way to survive, and reemerge even stronger under a new leader.

\section{VIETMINH}

In early I94I, as the French were hunting down his comrades, Ho Chi Minh returned to Vietnam for the first time in three decades. He set up camp at Pac Bo, in the northwestern province of Cao Bang, by the border with China. His detractors within the ICP either dead, in jail, or on the run, Ho could finally take command of the Party and steer it in the direction he wanted. Following the end of his studies in Moscow in 1938, Ho had spent time with Chinese communists at their base in Yan'an Province, the endpoint of the Long March (1934-5) that served as the main base of operation of the Chinese Communist Party (CCP) until I949. Since then he had become an avid student of the thoughts of Mao Zedong (I 893I976), who became CCP leader during the Long March, on MarxismLeninism and revolution. As China's circumstances resembled Vietnam's own, Vietnamese communists could learn much from the struggle of their Chinese counterparts, Ho felt. Besides, Ho was never fond of the Stalinist/Comintern revolutionary line. He had tussled with other ICP leaders over it, and been marginalized because of it. "Maoist formulations of internationalism," historian Mark Philip Bradley has written, provided Ho with "an alternative to Soviet models for the national liberation struggle that fit indigenous realities and prompted an ideological affinity with China that would persist and deepen after I940." เo For the past ten years the ICP had followed Moscow's counsel; where had that gotten it? In April I94 I, the Soviet Union signed a pact of non-aggression with the ultra-nationalist, fascist government of Japan. That shocked Ho and other Vietnamese revolutionaries, encouraging them to pursue closer collaboration with Mao.

Inspired by and per prior agreement with Mao and the CCP, on I9 May I94I, the day of his fifty-first birthday, Ho announced the creation of an indigenous united front to fight French and Japanese imperialism in Indochina. The Vietnam Independence League, commonly known in the West as Vietminh (abbreviated from the Vietnamese Viet nam Doc lap Dong minh Hoi), was a broad-based political and military resistance front that rallied fighters and partisans from all segments of Vietnamese society to liberate the nation and secure its independence. With help from Vo Nguyen Giap, a young lawyer and high-school History teacher turned revolutionary whom he had recently met in China, Ho organized 
month-long military and political training sessions for groups of fifty to sixty rebels in Cao Bang. Recruits learned how to fight, as well as how to engage civilians to win their hearts and minds. Ho was completely sold on the Maoist premise that winning over the people - political struggle - was as crucial if not more fundamental than physically eliminating enemies - military struggle. As Mao's own adage went, rebels must be able to "move amongst the people as a fish swims in the sea." Purportedly patriotic, the Vietminh actually answered to the ICP and to Ho in particular, who downplayed his own ties to communism to broaden the appeal of his organization and encourage more people to join it.

The united front approach marked an important shift in the ICP's revolutionary strategy. Starting in I94I, as Ho's influence in the Party became more pronounced, the ICP ceased toeing the Soviet line and moved toward closer, fuller ideological alignment with Mao and the CCP. As a result of that alignment, the line of struggle espoused by Ho and the ICP became consonant with the "people's war" strategy developed and applied by Mao in China. That strategy called for concerted efforts to drum up support among civilians through propaganda and other political activities, on the one hand, and wage guerrilla warfare (hit-and-run attacks) against the enemy's most isolated and vulnerable military assets to frustrate and demoralize him until he surrendered, on the other. Consistent with the thinking of Russian Bolshevik revolutionary Nikolai Bukharin (I888-1938), endorsed and applied by Mao in his own country, the ICP looked to peasants, the overwhelming majority of the population, to provide fighters and otherwise support its activities. Mao in particular rejected the orthodox premise that communism could only take root in industrialized societies, that industrialization was a prerequisite for communism. Unlike European Marxist-Leninists who held that workers must form the revolutionary backbone, Mao believed peasants could just as easily assume that role in predominantly agrarian societies like China and Vietnam. The latter could even bypass the stage of capitalist (industrial) development and jump straight to communism, he thought.

At the onset, the Vietminh could do little more than harass French and Japanese forces due to its very limited human and material resources. Still, the valiance of its fighters did not go unnoticed by their compatriots, who applauded their efforts as the "cowardly" French kowtowed to and collaborated with the Japanese. While in China in I 942 to meet CCP leaders, Ho was arrested by Chinese Nationalist (GMD) authorities, Mao's archrivals, and spent the next two years in jail. Despite his 
absence, the Vietminh persevered, gaining more supporters and acquiring better weapons by raiding French and Japanese armories. Shortly after Ho's return to Vietnam, in December 1944, a group of elite Vietminh fighters comprising thirty-one men and three women came together to form the Armed Propaganda Unit for National Liberation under Giap's command. The elite unit's mission was both military and political, and included winning over civilians through "education" sessions, that is, propaganda; recruiting and training new combatants; and acting as vanguard in the armed struggle for independence. Creating this "mobile main force" unit, as ICP leaders called it, fell within the parameters of people's war. Today, the formation of the unit is celebrated in Vietnam as marking the founding of the People's Army of Vietnam (PAVN), the country's standing armed forces.

In early 1945, a famine resulting from a combination of wartime dislocations and natural disasters struck Tonkin and Northern Annam. Vietminh efforts to alleviate the ensuing suffering of peasants in hardest-hit rural areas by raiding government granaries and rice transportation systems and handing over their loot to the starving masses raised the organization's profile, and Ho's and the ICP's by extension. The famine still claimed between 500,000 and one million lives, nearly a tenth of Tonkin's population of seven million at the time. But as historian Huynh Kim Khanh has argued, Vietminh attempts to mitigate its effects - futile as they were - in the end played a seminal role in the rise of the ICP in Vietnam and of Ho as savior and redeemer of the Vietnamese. ${ }^{\text {II }}$

The French in Vietnam suffered a devastating blow in spring 1945, when Japan unilaterally abrogated its I94I pact with the Vichy government. In the so-called coup of 9 March, Japanese troops attacked French military garrisons and raided administrative offices, killing some 800 Frenchmen, mostly members of the armed forces. They jailed surviving ranking members of the French armed forces and colonial government, and confined to urban neighborhoods and makeshift camps nearly 30,000 other French nationals, military and civilian. Desperate to win Vietnamese support as the tide of the war was turning against them, the Japanese restored on Io May I945 the "Empire of Vietnam" under the Nguyen sovereign, Bao Dai (I9I3-97), who at once proclaimed the independence of his country from France. Days later, Bao Dai, supported by Japan, announced the formation of a nominally autonomous government under Prime Minister Tran Trong Kim (I883-I953) which officiated over the formal reunification of the nation. The inability of the French to even 
protest the Japanese betrayal of their "alliance" attuned Ho and other patriots to the precariousness of France's position in Indochina.

\section{AMERICAN CONTACTS}

World War II was also a turning point for American policy in Southeast Asia. Prior to the war, the United States had expressed little interest in Indochina, recognizing it as a French sphere of influence. Admittedly, France's mercantilist policy and its monopolies had deterred both the American government and private firms and citizens from seeking economic and other opportunities there. Only a handful of Americans had been to Indochina, to do business, proselytize, or play tourist, as previously noted. Relatives of President Theodore Roosevelt (in office I90I-9) owned a hunting lodge in Ban Me Thuot, in the Central Highlands, used during expeditions to hunt tigers and other exotic wildlife (that lodge became a US military regional headquarters during the Vietnam War). Other than being the source of certain raw materials, the region meant little to Americans.

Japan's invasion changed all of that. Tokyo's pursuit of a Greater East Asia Co-Prosperity Sphere and, specifically, push into Southeast Asia following the invasion of China, alarmed the administration of President Franklin D. Roosevelt (in office I933-45). The latter feared not only an impending move by Japan against the American colony in the Philippines, but also the loss of access to Indochinese rubber and tin upon which the United States depended rather heavily. Following the first VichyTokyo agreement and the movement of Japanese troops into Indochina, Washington had slapped sanctions on Japan. Those sanctions prompted Tokyo to plan and eventually carry out an attack on the US naval base at Pearl Harbor in Hawaii. The collusion of Vichy authorities with Japan, a strong personal dislike of Free France leader Charles de Gaulle, the conviction that French colonialism had brought nothing but misery to the peoples of Indochina, and a firm desire to end colonial monopolies and open the region to American commerce prompted Roosevelt to insist as early as I940-I that France not be allowed to retain Indochina after the war ended, and that the region become an international trusteeship, much as Middle Eastern countries had become after World War I, instead.

Despite Ho's known ties to communism, the Roosevelt administration considered the Vietminh an ally in the war against Japan after I94I. Stalin's mid-I943 decision to dissolve the Comintern, to which the ICP had belonged, made working with Ho more palatable to the Americans. 
The Vietminh aided the allies by not only fighting - harassing, really - the Japanese, but also rescuing US pilots downed over Indochina. In July I945, a team from the American Office of Strategic Services (OSS), the precursor to the Central Intelligence Agency (CIA), parachuted into the Vietminh's main base to train and equip some of its fighters. Ho, who had been battling dysentery and malaria for months, allegedly was on the brink of death when the OSS team arrived. An American corpsman saved his life. In the brief time they were there, OSS members developed a very favorable impression of their hosts. They were particularly impressed with Ho, and moved by his ideals and commitment to their realization.

\section{AUGUST REVOLUTION}

By the time World War II ended in Asia in August I945, Ho was a friend of the United States. He was also the face of Vietnam's struggle for freedom and independence to his compatriots. Indeed, the war allowed his communist party to gain wider acceptance as a legitimate patriotic political organization, despite counting less than 5,000 registered members when hostilities ended. Japan's savage exploitation of human and material resources in Indochina and the rest of Southeast Asia had also validated ICP claims that World War II was a product of capitalist greed, a devastating contest between imperialist powers seeking self-aggrandizement through acquisition of new colonies and markets. That, in conjunction with the Vietminh's valiant efforts during the war, made Vietnamese of all social standings more receptive to ICP propaganda. Ho and the rest of the Party leadership learned a valuable lesson from their wartime experience, namely, that downplaying their Marxist-Leninist credentials facilitated popular mobilization domestically and abroad. That same experience, grueling for most Party leaders, also solidified their own personal devotion to communism.

World War II, like World War I before it, disgraced the French in the eyes of the Vietnamese. In fact, it sealed their fate in Indochina. The Japanese had effectively abolished French colonial rule through their coup of March I945. If the postwar government of Charles de Gaulle in Paris decided to reinstate French rule, as it would soon attempt to do, at least the Vietnamese now knew that the French were far from invincible. Ho Chi Minh understood this better than anyone. No sooner had the war in Asia ended than he and the ICP instigated the "August Revolution," a general uprising of the population spearheaded by the Vietminh to fill the political vacuum after Tokyo capitulated, before the French had a chance 
to reclaim control. The Vietminh improved its capabilities by commandeering weapons from the Japanese, who saw no reason to resist. It also bolstered its ranks and popularity by abolishing the despised government monopolies over alcohol, opium, and salt, and adopting other policies that pandered to people's basic needs and wants. On I 9 August, Vietminh units marched into Hanoi accompanied by the OSS team for added legitimacy. By orders of the ICP, those units occupied government buildings and took charge of or otherwise provided security for such facilities as power plants, hospitals, and prisons. Opposition was non-existent. In fact, most people enthusiastically welcomed the Vietminh power grab. The regime only recently created by the Japanese under Bao Dai, the Nguyen Emperor, remained silent. The French, for their part, were in too much disarray, with too many of their leaders and soldiers still in jail, to respond. Across the countryside, peaceful popular upheavals, celebrations of the end of the war for the most part, culminated in the formation of "people's committees" under ICP loyalists who assumed local administrative responsibilities thereafter.

After seizing power in Tonkin, the Vietminh and the ICP set their sight on Annam and its most important city, Hue, the imperial capital. On 25 August, under pressure from the ICP, Bao Dai abdicated the throne, ending the thousand-year old dynastic system in Vietnam. This was arguably the most revolutionary aspect of the August Revolution. A provisional government was formed two days later, with Ho as chairman. By that time Cochinchina was under the control of the Vietminh, though the latter's position there was more precarious. Neither the Vietminh nor the ICP enjoyed widespread support in the deep South. What is more, religious sects and other factions there did not trust or had no interest in collaborating with the Vietminh and Ho's new regime. The creation of a regional administrative committee in Saigon dominated by the ICP infuriated them, validating as it did their concerns that the August Revolution was in fact nothing more than a communist power grab.

Over ensuing days, the newly minted Provisional Government consolidated its authority as Vietminh units sought to preempt a counterrevolution by the French and other groups opposed to them. To these ends, they neutralized actual and potential opponents by offering them positions in the new administration, or detaining or killing them. Before the end of the month Ho and the Vietminh had assumed de facto control of most of the country. In retrospect, the ICP termed this series of developments the "August Revolution" less to capture its essence than 
to dramatize and legitimize an otherwise prosaic, banal, even fortuitous seizure of power.

\section{DECLARATION OF INDEPENDENCE}

The August Revolution culminated on 2 September 1945, at Place Puginier (later renamed Ba Dinh Square) in Hanoi, when Ho Chi Minh declared the country's independence and reunification, and proclaimed the advent of the Democratic Republic of Vietnam (DRVN) as a fully sovereign state. Ho's proclamation opened with the following lines:

All men are created equal; they are endowed by their Creator with certain inalienable Rights; among these are Life, Liberty, and the pursuit of Happiness. This immortal statement was made in the Declaration of Independence of the United States of America in I776. In a broader sense, this means: All the peoples on the earth are equal from birth, all the peoples have a right to live, to be happy and free. The Declaration of the Rights of Man and Citizen of the French Revolution made in I79I also states: All men are born free and with equal rights, and must always remain free and have equal rights. Those are undeniable truths.

The references to the American Declaration of Independence and the French Declaration of the Rights of Man and Citizen were deliberate. Ho insisted on them to suggest that Vietnam intended to maintain close ties with the West even after independence, and thus pander to public opinion in France and the United States in particular with a view to preempting the resumption of French colonial rule.

Archimedes Patti (I9I3-98), an OSS agent working with the Vietminh in Hanoi at the time, was stunned when he read the draft text of the Proclamation handed to him by Ho himself. In its tone and substance, the Proclamation exulted freedom and self-determination, and made no allusion to social revolution and class struggle, tell-tale signs of allegiance to communism. The effort to conceal the ideological leanings of the country's new leaders also included appointing the former Emperor, Bao Dai, Supreme Adviser to the new DRVN government. Patti and other OSS staff on-site applauded Ho's proclamation and his new regime. Given the Vietminh's wartime support for the allied cause, they mistakenly concluded that Ho was first and foremost a patriot whose attachment to communism was only skin-deep and self-serving at best.

Unfortunately for Ho, Paris paid no heed to and in fact outrightly rejected the Proclamation. The newly-installed provisional government of Charles de Gaulle, it turned out, had no desire whatsoever to hand Indochina over to the Indochinese. Colonies attested to France's big 
power status; in light of the national humiliation suffered in World War II, de Gaulle felt France could not afford to lose its empire. Washington privately objected to de Gaulle's decision, but made no effort to dissuade him. Before his death in April I945, Roosevelt had made an about-face on Indochina, and dropped the trusteeship idea largely because the British vehemently opposed it. His successor, Harry Truman (in office 1945-53), preferred appeasing de Gaulle in hopes of securing his cooperation in restructuring postwar Europe and, perhaps more importantly, checking Soviet ambitions there and elsewhere. The nascent Cold War and, specifically, concerns about the Soviet occupation of East Europe, future of Germany, and spread of communism in the West soon consumed the Truman administration, and conditioned its policy vis-à-vis France and Indochina.

Seeking to convince the United States to reconsider its stance, in fall I945 DRVN authorities founded the Vietnamese-American Friendship Association in Hanoi. The Association sponsored English-language courses, translations of American books into Vietnamese, and showings of American films. It even hosted representatives and agents from major US firms such as Texaco, General Motors, and Harley-Davidson interested in doing business in Indochina. The prospect of enhanced cultural and, more significantly, economic exchanges might, Ho's new government reasoned, prompt Washington to reexamine its relationship with the DRVN. After all, the French had never been particularly receptive to American economic activity in Indochina. American policymakers were unmoved.

The indifference of the United States plus de Gaulle's intractable stance unnerved Ho and other ICP leaders. Equally unsettling, no government recognized the sovereignty and legitimacy of the DRVN in the weeks and months after 2 September, not even the Soviet Union. Domestically, at least, Ho's declaration of independence electrified the population. Mass celebrations broke out throughout the country. Roused peasants seized land belonging to their landlords and wealthier peers. The Vietminh's popularity soared, as did membership in the Communist Party. Tragically, anti-French pogroms ensued in certain cities, resulting in the killing of dozens of innocents, including a French priest who was stabbed to death. Paris would not soon forget this and other injustices perpetrated against its nationals.

\section{Notes}

I William S. Turley, The Second Indochina War: A Concise Political and Military History [2nd ed.] (Lanham: Rowman \& Littlefield, 2009), 9, Io. 
2 To illustrate, peasants revolted on more than 400 occasions during the first sixty years of rule by the Nguyen Dynasty (I 802-I945), Vietnam's last.

3 Mark Moyar, Triumph Forsaken: The Vietnam War, I954-I965 (New York: Cambridge University Press, 2006), 2.

4 Edward Miller (ed.) The Vietnam War: A Documentary Reader (Malden, MA: Wiley Blackwell, 2016), xiv.

5 Céline Marangé, Le communisme vietnamien, I9I9-I99I [Vietnamese Communism, I9I9-I99I] (Paris: Presses de Science Po, 2012), 46.

6 Tuong Vu, Vietnam's Communist Revolution: The Power and Limits of Ideology (New York: Cambridge University Press, 20I7), 33.

7 Sophie Quinn-Judge, Ho Chi Minh: The Missing Years, I9I9-I94I (Berkeley: University of California Press, 2003 ), 257.

8 Odd Arne Westad, The Global Cold War: Third World Interventions and the Making of Our Times (New York: Cambridge University Press, 2005), Io8.

9 Quinn-Judge, Ho Chi Minh, 42. In a recent study, Tuong Vu takes exception to Quinn-Judge's and others' interpretation. See Tuong Vu, Vietnam's Communist Revolution, 46-5 I.

Io Mark Philip Bradley, Imagining Vietnam and America: The Making of Postcolonial Vietnam, I9I9-I950 (Chapel Hill: University of North Carolina Press, 2002), 4I.

I I Huynh Kim Khanh, Vietnamese Communism, I925-I945 (Ithaca: Cornell University Press, I982), 3 I 2-I 5. 